\title{
Immune Responses to Fed Protein Antigens in Mice. 3. Systemic Tolerance or Priming Is Related to Age at Which Antigen Is First Encountered
}

\author{
STEPHAN STROBEL ${ }^{(32)}$ AND ANNE FERGUSON \\ Gastro-Intestinal Unit, University of Edinburgh and Western General Hospital, Edinburgh, Scotland, UK
}

\begin{abstract}
Summary
The normal effect of feeding an antigen, such as ovalbumin (hens' egg albumin), to adult animals is the induction of a state of specific nonreactivity of the lymphoid tissues when the same antigen is presented again (oral tolerance). We have carried out feeding experiments in neonatal mice to investigate subsequent immune responses after physiologic antigen exposure and to examine the role of the neonatal intestine.

We demonstrate for the first time that feeding a weight related dose of ovalbumin within the first week of life results in priming for both humoral and cell-mediated immune responses, despite the profound tolerance found in adult animals when treated in the same way. When the time scale of antigen exposure was extended into the prenatal period, the enhancement of the immune response was even more pronounced. These effects are long lasting and effects on cell-mediated immune responses are still demonstrable $14 \mathrm{wk}$ after the initial priming feed. We postulate that after an antigen feed in the neonatal period, immunologic and digestive immaturity lead to a net gain in $T$ help which prevents the induction of systemic hyporesponsiveness (oral tolerance).
\end{abstract}

\section{Abbreviations}

CFA, complete Freund's adjuvant

CMI, cell-mediated immune responses

DTH, delayed type hypersensitivity

ELISA, enzyme-linked immunosorbent assay

OVA, ovalbumin

SAL, saline

Although the usual effect of antigen exposure is induction of an active immune response, this is not always the case. Immunologic hyporesponsiveness (tolerance) may also result, and one of the most effective ways to induce this is to feed antigens (12, $26,28,30$ ). Although it has been known for over $70 \mathrm{yr}$ that feeding of protein antigen to experimental animals leads to specific immunologic hyporeactivity (30), the precise mechanisms responsible for this oral tolerance are still unclear (27). Patients with food allergic diseases exhibit active systemic immunity to food antigens-implying that in place of oral tolerance, priming or sensitisation resulted from the feeding of antigen. The induction of similar abnormal immune responses in animals would provide a model for investigation of this group of important diseases. Because food allergic disease in humans is a feature of infancy, there is special interest in defining the mechanisms that regulate immune responses to fed antigens in neonates.

Tolerance is very readily introduced in neonatal animals when antigen is given by routes other than via the gut. This has been demonstrated with many different forms of antigen including allogeneic cells (2), skin sensitising agents (22), and aggregated human gammaglobulin (9). In view of this relative ease of tolerance induction in the neonatal period, it might be expected that oral tolerance would normally be even more profound and complete in neonates than in adults. In the only report of relevant experiments, in which the antigen ovalbumin was fed to neonatal mice, however, Hanson (13) found priming for subsequent humoral responses, and not oral tolerance. The effects of neonatal feeding on subsequent CMI responses have not been described. We have therefore undertaken a series of experiments, to examine how the age of an animal influences specific systemic immune responses to a fed antigen, either oral tolerance or oral sensitisation (priming). Serum antibody and systemic CMI responses were studied, and the results are discussed in the context of the ontogeny of immunoregulatory $\mathrm{T}$-cell functions.

\section{MATERIALS AND METHODS}

General. Repeated oral or parenteral antigen exposure caused no ill effects, such as shock or anaphylaxis. The mortality or exclusion rate of animals fed on the first day of life was less than $4 \%$.

The ELISA assay for serum antibodies was developed while these experiments were in progress and extensive comparisons between ELISA and passive haemagglutination technique showed a good correlation ( $r=0.949$ in a group of 65 specimens) over a haemagglutination antibody titre range from one in five to one in $7680(P<0.001)$.

Feeding of antigen did not induce systemic immunity when this was tested in three separate experiments. A single feed of OVA to adult mice induced oral tolerance both for humoral antibody responses (74-92\% suppression in 11 experiments) and for CMI (78-96\% suppression in 13 experiments).

Animals. Three strains of mice were used in these experiments: $\mathrm{BDF}_{1}(\mathrm{C} 57 \mathrm{BL} 6 \mathrm{~J} \times \mathrm{DBA} / 2), \mathrm{BALB} / \mathrm{c}$, and CBA. These were bred in the Animal Unit of the Western General Hospital, Edinburgh. All animals were fed Spratt's rodent diet (Spratt's Ltd, Barking, Essex, UK), which does not contain ovalbumin. Mice were weaned on to this diet at $21 \mathrm{~d}$ of age and were kept on a $12-\mathrm{h}$ light/dark cycle with water supplied ad libitum. For defining the age of the pups, the breeding pairs were checked twice per day ( 9 AM, 5 PM) and litters delivered before 9 AM were assigned a birth date corresponding to the preceding day. Animals treated at $\mathrm{d} 1$ were placed in experiments on the morning they were discovered and were, thus, aged between 16-24 h.

Antigens. Ovalbumin (Fraction V) and bovine serum albumin (Fraction V) were obtained from Sigma Chemical Company (Poole, Dorset, UK). These were dissolved in $0.15 \mathrm{M}$ saline at a concentration of $100 \mathrm{mg} / \mathrm{ml}$ 
Intragastric administration of antigen. Experimental animals were not fasted. Mice aged 3 wks and more were intubated with a 19 gauge stainless steel feeding tube. Younger mice were intubated with 00 intravenous tubing (Portex Ltd, Hythe, Kent, UK) attached to a 26 gauge needle stock. In order to prevent abrasion and minimise trauma, the end of the feeding catheter was blunted by heating and checked for smoothness under a dissecting microscope. In some experiments a modified catheter with a flexible silicone rubber tip (SILASTIC, Dow Corning, USA) was used. Experimental animals which showed signs of regurgitation or bleeding after feeding were excluded. In most experiments, the intragastric dose was $1 \mathrm{mg}$ antigen/g body weight. In experiments where dose dependence of tolerance induction was assessed, the concentration of $\mathrm{OVA} / \mathrm{ml}$ was adjusted so that the maximum volume given did not exceed $0.3 \mathrm{ml}$ in adult mice or $0.05 \mathrm{ml}$ in neonatal mice. Control animals were given either $0.15 \mathrm{M}$ saline or water by intragastric intubation.

Systemic immunisation. For assessment of systemic humoral and CMI responses, animals were immunised with $100 \mu \mathrm{g}$ OVA emulsified in an equal volume of CFA (H37Ra, Difco Ltd, East Molesey, Surrey, UK) and $0.05 \mathrm{ml}$ was injected into one rear footpad under ether anaesthetic. Preliminary experiments showed that this regime was effective in eliciting vigorous humoral and CMI responses $3 \mathrm{wk}$ after immunisation.

Bleeding of the mice. Mice were bled from the retro-orbital venous plexus under ether anaesthesia, and approximately 200 $\mu \mathrm{l}$ of blood were collected into heparinised haematocrit tubes (Propper Co. Inc., Long Island, NY, USA). Sera were separated, and heat inactivated by incubating at $56^{\circ} \mathrm{C}$ for $30 \mathrm{~min}$, and were then stored at $-20^{\circ} \mathrm{C}$.

Footpad testing for DTH. Three weeks after immunisation with OVA in CFA, DTH was measured by using a footpad swelling test. Footpad thickness was measured with microcalipers (Carobronze Ltd, London, UK) before and $24 \mathrm{~h}$ after an intradermal injection of $100 \mu \mathrm{g}$ OVA in a volume of $0.05 \mathrm{ml}$. As controls, mice that had been immunised with adjuvant alone were also skin tested with $100 \mu \mathrm{g}$ OVA. There was no significant footpad swelling in these control mice at $24 \mathrm{~h}$ after intradermal antigen administration.

Serum antibodies. Sera were tested for anti-OVA antibodies by two techniques, passive haemagglutination and ELISA. Passive haemagglutination of sheep erythrocytes coated with chromic chloride (BDH Chemicals Ltd, Poole, Dorset, UK) was performed as previously described (17). ELISA microtitre (LIN$\mathrm{BRO}$, Flow Laboratories, Irvine, Ayrshire, UK) plates were coated with $0.1 \mathrm{mg} / \mathrm{OVA}$ in $0.03 \mathrm{M}$ carbonate buffer $\mathrm{pH} 9.6$ for $2 \mathrm{~h}$ at $37^{\circ} \mathrm{C}$. Serum samples diluted to $1 / 100$ were left at room temperature for $5 \mathrm{~h}$ and heavy and light chain specific goat antimouse alkaline phosphatase coupled conjugate (Northeast Biomedical, Uxbridge, UK) was added in a working dilution of $1 / 1000$ and incubated for $16 \mathrm{~h}$ (overnight). Substrate ( $p$-nitrophenylphosphate, Sigma Chemical Company) was dissolved at 1 $\mathrm{mg} / \mathrm{ml}$ in $10 \%$ diethanolamine buffer and the absorbance read with a Dynatech automatic reader (Dynatech Ltd, Billingshurst, Sussex, UK) at $405 \mathrm{~nm}$. Saline, $0.15 \mathrm{M}$, with $0.05 \%$ Polysorbate 20 (Sigma Chemical Company) was used as washing solution between each step.

Intra-amniotic administration of antigen. Pregnant females, on d 19 of gestation, were anaesthetised intraperitoneally with $0.06 \mathrm{mg}$ pentobarbitone sodium (SAGATAL, May and Baker Ltd, Dagenham, UK) per gram body weight. Mice were restrained on a warm plate, the abdominal wall was incised in the midline, and, in turn, the right and left halves of the uterus were lifted out of the abdominal cavity on to a damp swab. The fetuses and the placenta were clearly visible and injections were performed into the amniotic sacks, by using a 30 gauge stainless steel needle. Antigen solution $(0.05 \mathrm{ml})$ or saline $(0.05 \mathrm{ml})$ was injected into each amniotic sack, care being taken to avoid blood vessels, and to ensure that there was no leakage of antigen solution or amniotic fluid. The uterus was then carefully replaced in its original position. The abdominal fascia was closed by using single atraumatic sutures $(4 \times 0$ ETHILON, Ethicon Ltd, Edinburgh, UK) and the abdominal wall closed with metal clips. Animals were kept on a warm plate for $2 \mathrm{~h}$ while they recovered from the anaesthetic.

Statistics. The $t$ test was used to compare results of skin test measurements and the passive haemagglutination titres $\left(\log _{10}\right.$ transformed) between groups. For the ELISA tests, absorbance readings between groups were compared by Wilcoxson's rank sum test. Correlation between passive haemagglutination and ELISA results were assessed by linear regression analysis.

\section{RESULTS}

Experimental protocol. Experiments were designed to investigate the following immunologic consequences of a feed of either antigen or saline.

1. Generation of systemic immunity by feeding.

2. Induction of priming (i.e., enhancement of the immune response to a parenterally administered antigen in animals without antibody or CMI responses before parenteral immunisation).

3. Suppression (tolerance) of the immune response when antigen-fed animals are compared with controls. Suppression was calculated by using the following formula:

$\%$ Suppression

$$
=\left(1-\frac{\text { response of antigen fed mice }}{\text { response of saline fed mice }}\right) \times 100
$$

Animals were fed OVA or saline (SAL) by intragastric intubation, or by intra-amniotic injection of OVA or saline, 24-36 h before birth. Four weeks later, serum was tested for antibodies, and skin tests were performed to detect CMI responses induced by this initial treatment (these tests were uniformly negative). Then, all animals were immunised with OVA in CFA parenterally and systemic antibody and CMI responses were measured by serum antibody determinations, and intradermal skin tests.

Effects of intragastric OVA administration to neonatal, immature and adult mice. Mice were fed OVA in a weight-related dose $(1 \mathrm{mg} / \mathrm{g}$ body weight) by intragastric intubation at the ages of $1,3,7,14$, and $42 \mathrm{~d}$. All animals were immunised with OVA in CFA $28 \mathrm{~d}$ later. Animals fed OVA between 1 and $7 \mathrm{~d}$ after birth did not develop oral tolerance. Indeed, mice fed $1 \mathrm{~d}$ after birth exhibited, repeatedly and consistently, signs of priming both for antibody responses and CMI (Figs. 1 and 2). Extrapo-

\section{Effects of OVA feeds at various ages on subsequent immune responses of $\mathrm{BDF}$ mice}

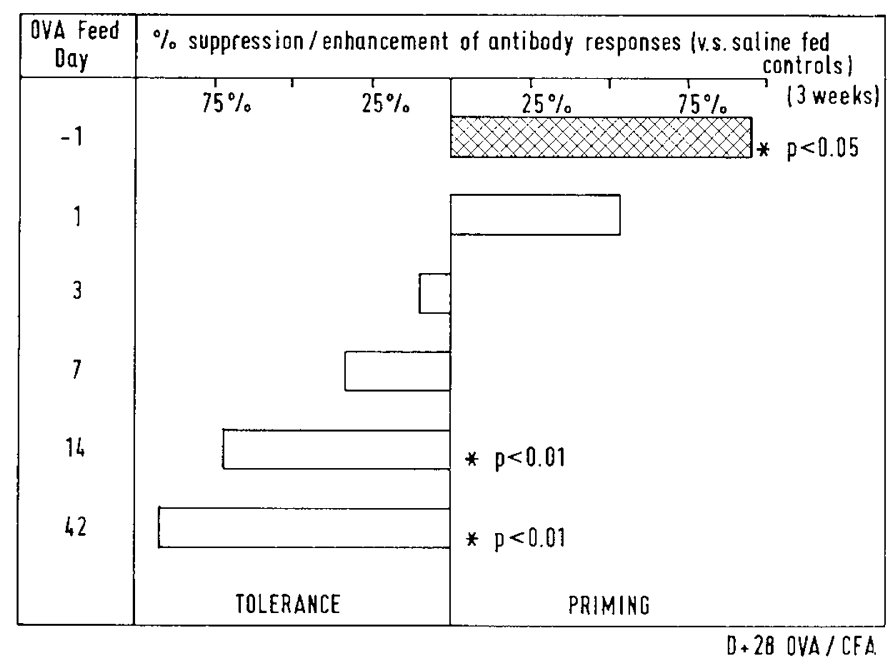

Fig. 1. Effects of ovalbumin (OVA) feeds at various ages on subsequent immune responses of $\mathrm{BDF}_{1}$ mice (antibody responses). 
Effects of OVA feeds at various anes on subsequent immune responses of $B D F_{1}$ mice

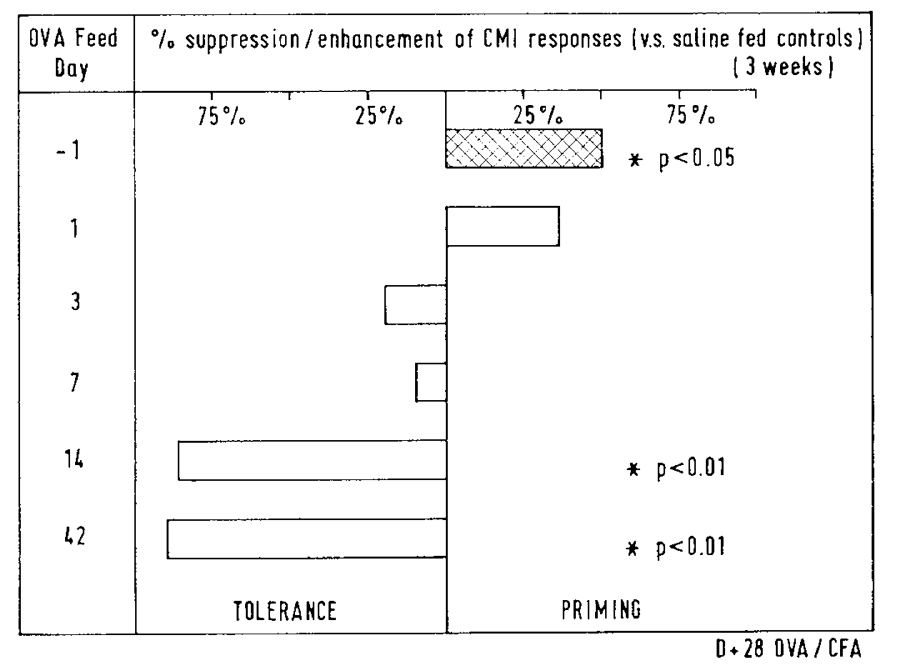

Fig. 2. Effects of ovalbumin (OVA) feeds at various ages on subsequent immune responses of $\mathrm{BDF}_{1}$ mice (cell-mediated immune responses).

Table 1. Enhancement of immune responses after feeding ovalbumin (OVA) on the first day of life in different mouse strains*

\begin{tabular}{|c|c|c|c|c|}
\hline \multirow[b]{3}{*}{$\begin{array}{l}\text { Strain } \\
\delta+q\end{array}$} & \multirow[b]{3}{*}{ Feed } & & \multirow{2}{*}{\multicolumn{2}{|c|}{$\%$ Enhancement }} \\
\hline & & & & \\
\hline & & $\begin{array}{l}\text { Age } \\
\text { (d) }\end{array}$ & $\begin{array}{l}\text { Antibody } \\
\text { responses }\end{array}$ & $\begin{array}{l}\text { Cell-mediated } \\
\text { immunity }\end{array}$ \\
\hline $\mathrm{CBA}$ & OVA & 1 & $+54,+10$ & $+36,+25$ \\
\hline $\mathrm{BALB} / \mathrm{c}$ & OVA & 1 & +41 & +26 \\
\hline $\mathrm{BDF}_{1}$ & OVA & 1 & $+51,+41+,+16$ & $+24,+31,+4$ \\
\hline
\end{tabular}

* All animals were immunised 4 wk after birth.

$\dagger \%$ enhancement of systemic immune responses compared with saline-fed littermate controls.

+ $P<0.01$.

lation from these data suggests that the crossover to significant tolerance induction occurs around the 10th $\mathrm{d}$ after birth.

Effects of $O V A$ feeds at $d I$ on systemic immune responses in different inbred mouse strains. In order to ensure that the observed priming effect by feeding antigen on the first day of life, was not specific for only one strain, two other strains of mice (CBA and BALB/c) were also tested. Feeding OVA on the first day of life led to qualitatively similar priming effects for both systemic antibody and CMI responses, in repeated experiments (Table 1).

Effects of weaning on the induction of tolerance to OVA. By the time mice were aged $14 \mathrm{~d}$, the magnitude of immunologic suppression produced by a feed of OVA was as complete as occurs in adult animals; however, this pattern was disturbed when animals were fed during the weaning period. In order to separate the effects of age and of weaning, animals were fed OVA or saline on the day of weaning, and 3 and $7 \mathrm{~d}$ on either side of this day. In some groups weaning was delayed for $3 \mathrm{~d}$ so that animals of identical age differed in their weaning date. The results are summarised in Table 2 . When mice were weaned at age 21 $\mathrm{d}$, and given an OVA feed on that day, they showed no subsequent oral tolerance for antibody responses, and less than usual suppression of CMI responses. On the other hand, littermates weaned $3 \mathrm{~d}$ after feeding or fed OVA $3 \mathrm{~d}$ after weaning showed significant oral tolerance both for humoral and CMI responses. When there was an interval of $7 \mathrm{~d}$ between the day of weaning and OVA feed, oral tolerance analogous to that found in adult animals was observed. The transient absence of oral tolerance in these mice aged $21 \mathrm{~d}$ was not age related, but the result of weaning.

Influence of prenatal antigen exposure. The following experiments were designed to give "oral" and "parenteral" antigen in utero, by injecting OVA into the amniotic sack (feeding) and by using intravenous injection of a pregnant female as a means of exposing the pups, systemically, to antigen. The experiments were carried out to examine whether the consistent priming, observed in animals fed antigen on the first day of life, could be increased by prenatal exposure.

Effects of prenatal intestinal antigen exposure. The weight of a mouse fetus on the 19 th day of gestation is around $1 \mathrm{~g}$. The fetuses were therefore exposed to $1 \mathrm{mg}$ OVA by intra-amniotic injection of OVA in $0.05 \mathrm{ml}$ volume. Results (Figs. 1 and 2, hatched bars) show that by extending the timescale of feeding experiments into uterine life, priming of the offsprings was further increased. As the amount of OVA which was, in fact, taken up by the fetus could not be exactly measured, the results are not completely comparable with the effect of closely controlled postnatal feeds. But they demonstrate clearly that antigen administration to fetuses does lead to an active priming of the immune response and that this effect extends into adult life.

Effects of intravenous OVA injections into pregnant females on their pups' susceptibility to tolerance induction later in life. Pregnant females were injected with OVA intravenously 24-36 h before delivery. The subsequently born pups were fed saline or OVA 4 wk after birth. All animals were then immunised with OVA in CFA and subsequent antibody and CMI responses measured as described above (Table 3 ). The results of these experiments show that intravenous OVA injection, in amounts similar to those used for intra-amniotic antigen administration, did not enhance immune reactivity in the pups. Systemic tolerance induction, produced by feeding OVA at the age of $28 \mathrm{~d}$, was identical in the pups of saline- and OVA-injected mothers.

Specificity of priming by intra-amniotic antigen injection. Priming for OVA responses was shown to be antigen-specific, because intra-amniotic administration of bovine serum albumin did not lead to enhancement of anti-OVA immune responses.

Attempt to tolerise neonatally primed animals by further oral antigen administration. A series of experiments were performed, in order to determine whether it is possible to modulate subsequent immune responses in animals given a priming dose of OVA in the neonatal period. Further feeds of OVA were given to the animals, either in the first few days of life or in young adult life. Theoretically, these could lead to increase in the priming effect or to the subsequent recreation of oral tolerance. It was particularly important to examine whether primed animals could be retolerised by one or more feeding regimens which extended into the period where young animals are usually tolerisable (by age $14 \mathrm{~d}$ ).

Effects of age, frequency, and total amounts of neonatal OVA feeds on subsequent immune responses. The different feeding schedules and antigen doses are summarised in Table 4. Animals were fed OVA or saline on the first day of life and 4 or $14 \mathrm{~d}$ thereafter. Two groups of animals were fed daily for 4 and $14 \mathrm{~d}$. The effect of antigen dose was examined by feeding the total amount which had been given to these groups of animals over 4 or $14 \mathrm{~d}$, in a single dose on the 4 th or 14 th $\mathrm{d}$ of life. Sham-fed control groups were incorporated into these experiments.

For simplicity, the groups have been identified $A$ to $G$ (see Table 4). Group A (one day 1 feed) demonstrates that the priming effect of a single OVA feed is still detectable after 2 wk, and Group B (two feeds; d 1, 14) shows that a single refeed does not reverse this effect. But the group of mice fed daily for the first 4 $\mathrm{d}$ of life (Group $\mathrm{C}$, four daily feeds) showed suppression of their antibody responses $(P<0.001)$ and reduced although not significantly suppressed $\mathrm{CMI}$ response $(P<0.1)$. In contrast mice receiving an identical total quantity of OVA in a single dose on the 4th d of life (Group D, one feed d 4) showed no suppression 
Table 2. Effects of ovalbumin feeds on tolerance induction in relation to age and time of weaning*

Day of feeding

$\%$ Suppression

\begin{tabular}{cc} 
Age & in relation to weaning \\
(d) & \\
14 & -7 \\
21 & -3 \\
21 & 0 \\
24 & +3 \\
28 & +7 \\
\hline
\end{tabular}

\begin{tabular}{|c|c|c|c|c|}
\hline$n \ddagger$ & \multicolumn{2}{|c|}{ Antibody responsest } & \multicolumn{2}{|c|}{ Cell-mediated immunity $\underset{P}{\dagger}$} \\
\hline 8 & 70 & $<0.02$ & 92 & $<0.001$ \\
\hline 0 & 52 & $<0.05$ & 97 & $<0.001$ \\
\hline 7 & 28 & NS & 33 & $<0.05$ \\
\hline & 43 & $<0.05$ & 75 & $<0.001$ \\
\hline & 82 & $<0.01$ & 90 & $<0.001$ \\
\hline
\end{tabular}

*All animals were immunised with $100 \mu \mathrm{g}$ ovalbumin/complete Freund's adjuvant $14 \mathrm{~d}$ after feeding.

$\uparrow \%$ Suppression of systemic immune responses after feeding $1 \mathrm{mg} / \mathrm{g}$ ovalbumin compared to saline-fed littermate controls.

$\ddagger$ Animals per group.

Table 3. Effects of intra-amniotic and maternal intravenous injection of ovalbumin (OVA) or saline (SAL) on subsequent immune responses of $B D F_{1}$ mice*

\begin{tabular}{|c|c|c|c|c|}
\hline $\begin{array}{l}\text { Injection at } \\
\text { age } 1 \mathrm{~d}\end{array}$ & Feed at age $28 \mathrm{~d}$ & $\begin{array}{c}\text { Specific } 24 \mathrm{~h} \\
\text { footpad increments } \\
(\text { mean } \pm 1 \text { SEM })\end{array}$ & $\begin{array}{c}\text { ELISA } \\
\text { absorbance at } 405 \mathrm{~nm} \\
(\text { mean } \pm 1 \text { SEM })\end{array}$ & $\begin{array}{l}\text { Animals } \\
\text { per group }\end{array}$ \\
\hline \multicolumn{5}{|l|}{ Intra-amniotic } \\
\hline SAL & SAL & $0.14 \pm 0.01$ & $0.523 \pm 0.18$ & 6 \\
\hline SAL & OVA & $0.03 \pm 0.004 \dagger$ & $0.317 \pm 0.05 \dot{\dagger}$ & 5 \\
\hline \multicolumn{5}{|c|}{ Intravenous (mother) } \\
\hline $8 \mathrm{mg}$ OVA & SAL & $0.13 \pm 0.01$ & $0.543 \pm 0.050$ & 6 \\
\hline $8 \mathrm{mg}$ OVA & OVA & $0.04 \pm 0.01 \dagger$ & $0.311 \pm 0.041+$ & 6 \\
\hline
\end{tabular}

* All animals were immunised with $100 \mu \mathrm{g}$ ovalbumin/complete Freund's adjuvant $7 \mathrm{~d}$ after feeding.

$+P<0.001$.

$\ddagger P<0.01$.

of their immune responses, i.e., were not tolerant. To investigate the effects of daily feeds in more detail, littermates were fed 1 $\mathrm{mg} / \mathrm{g}$ body weight OVA for $14 \mathrm{~d}$ (Group E, 14 daily feeds) or received the same amount of OVA $(50 \mathrm{mg})$ on one occasion (Group F, one feed d 14). One OVA feed at age $14 \mathrm{~d}$ tolerises an animal as expected (Group F); however, the same quantity of antigen given in divided doses on $\mathrm{d} 1$ and 14 of life only suppressed subsequent antibody responses (Group C). When the same quantity of OVA was split into 14 daily doses (Group E), animals were subsequently tolerant. This implies that multiple daily feeds of OVA are more effective than a single feed of the same total amount in suppression of delayed type hypersensitivity responses.

Persistence of priming in animals fed OVA on the first day of life and refed OVA at various times thereafter. Animals were fed OVA on the first day of life and attempts were made to retolerise these mice by an OVA feed 2, 4, 6, 10, and $14 \mathrm{wk}$ after the initial treatment. The results are illustrated in Figure 3. Primed antibody responses were found to be partially suppressable by an OVA feed only $2 \mathrm{wk}$ after the initial priming dose and they were indistinguishable from those of tolerant animals when retolerisation was performed $4 \mathrm{wk}$ after the initial treatment. On the other hand, $\mathrm{CMI}$ responses exhibited a striking disparity and retolerisation was not accomplished before $14 \mathrm{wk}$.

Persistence of priming in animals that received intra-amniotic OVA and were refed OVA at age $28 d$. OVA or saline was administered intra-amniotically by injection $24-36 \mathrm{~h}$ before birth, and the pups were subsequently fed OVA or saline at age $28 \mathrm{~d}$. Results in the intra-amniotic saline group show that this manipulation had no effect on the capacity of the pups to respond in a normal manner (by oral tolerance) when OVA was first administered by feeding at age $28 \mathrm{~d}$. On the other hand, animals that had been exposed to ovalbumin by intra-amniotic injection demonstrated oral tolerance for serum antibody responses when retolerisation was attempted by feeding OVA 4 wk after birth, whereas tolerance for $\mathrm{CMI}$ responses was not present in the same animals (Table 5). These experiments demonstrate that prenatal antigen exposure had similar effects on subsequent immune responses as did feeding on the first day of life (Fig. 3).

\section{DISCUSSION}

Whereas feeding of a weight-related dose of OVA to adult mice consistently produces tolerance $(12,26,28)$, we have demonstrated in this study that when an equivalent dose is fed to neonatal mice within the first week of life, oral tolerance does not occur. Furthermore, animals fed on d 1 of life were primed, and when fetuses were exposed to antigen via intra-amniotic administration, an even greater priming of subsequent systemic immune responses occurred. These results confirm and extend the previous report (13) that a feed of OVA to mice on the first day of life primes for subsequent antibody responses. We attempted to modulate or reverse this priming phenomenon in two ways: by a retolerisation feed and by varying the antigen dose and frequency. The priming effects persist for several weeks but it proved possible to create a state of tolerance for systemic antibody responses by another tolerising feed 4 wk after the neonatal feed; for CMI, however, the state of non-tolerance persisted for $14 \mathrm{wk}$. In addition, we demonstrated that several daily doses of antigen (starting on d 1) induced tolerance whereas the same total dose fed on a single occasion did not.

Failure to induce tolerance by an important physiologic route of antigen exposure is in striking contrast to the generally recognised pattern that neonatal mice are very readily tolerised by antigen given by other routes $(2,5,9)$. It has been reported that a feed of human gammaglobulin tolerises neonatal mice, in contrast to the priming effect of feeding OVA (13) and this was interpreted by Hanson to be a dose-related phenomenon. Human gammaglobulin is, however, an atypical substance to use as an antigen for investigating immune responses to dietery antigens because of its preferential absorption and handling by the neonatal gut $(3,17)$. 


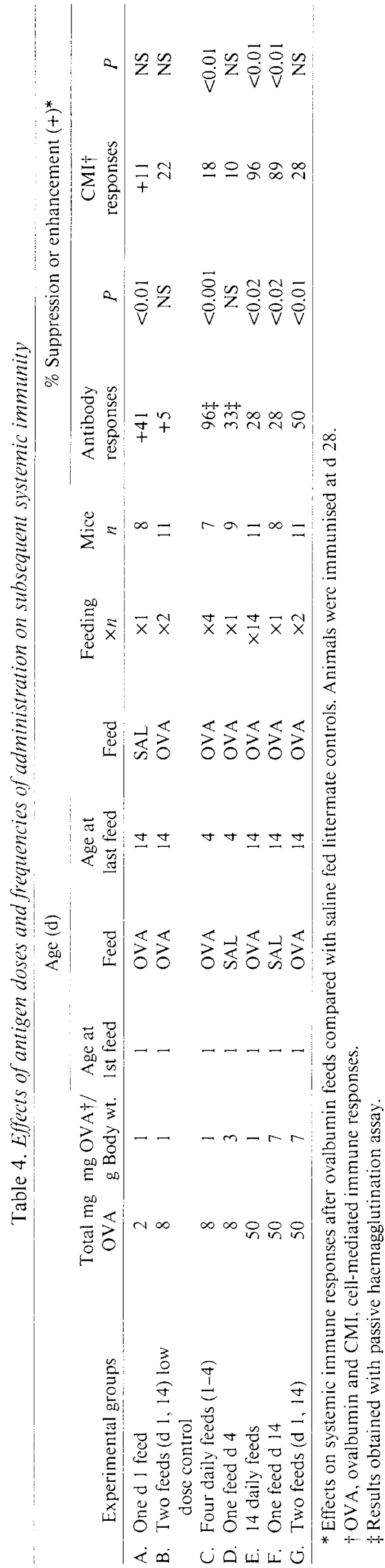

The development of the small intestine in baby mice occurs in stages with a rapid series of changes around the time of weaning in the $3 \mathrm{rd} \mathrm{wk}$ of life. The immunologic effects of fed antigen also follow an age-related pattern with the change from tolerance to non-tolerance at about $10 \mathrm{~d}$. This is before closure (17), brush-border enzyme development (11), intraepithelial lymphocyte, and plasma cell infiltration (10) of villi. On the other hand, the organised lymphoepithelial organs of the intestine, the Peyer's patches, are already populated by T cells $3-4 \mathrm{~d}$ after birth $(14,15)$. Thus there are no clear-cut relationships between changes in in vivo immune effects and the well established patterns of enterocyte and lymphoid maturation of the gut. The general pattern of increasing ease of tolerance induction after 10 $\mathrm{d}$ of age was briefly interrupted around the time of weaning. This was clearly related to the weaning and feeding interval and not to age. At weaning there is not only exposure to many new dietary antigens, but also withdrawal of maternal milk and changes in gut flora. All of these are candidate mechanisms for the temporary reduction of tolerance we observed.

Experiments in adult mice have shown that several different immunologic mechanisms are involved in oral tolerance. These include T suppressor cells $(18,19,21)$, circulating antigen antibody complexes (1), and anti-idiotypic antibodies (16). Immaturity of any of these immunologic functions could explain the absence of oral tolerance and the priming effect produced by feeding neonates and fetuses. Nevertheless, it is known that the fetus responds to antigenic stimuli, and that fetal or neonatal cells can act as adult cells when they are transferred into an adult environment (6). It has been established that there exists in neonatal, but not in adult mice, a population of nonspecific $T$ suppressor cells $(20)$. It seems unlikely that these have a role in perinatal priming but this is still conceivable in view of the complex T-T cell interactions involved in an orderly immune response. Hanson (13) produced evidence that priming for antibody responses in the neonate is due to direct effects of antigen on B cells. But because we showed systemic CMI effects too, there must also be direct or indirect $\mathrm{T}$ cell involvement.

The immunologic effects of feeding in the neonatal period may, however, be unrelated to the state of maturity of the lymphoid system. It is equally possible that immaturity of the neonatal digestive and absorptive functions is the key factor (4). The permeability of the neonatal gut to macromolecules is increased, as, for example, demonstrated by high concentrations of serum antigen after feeding $(8,29)$. Although the quantity of a circulating antigen may be important, the immunochemical properties and characteristics of absorbed antigen may be equally as relevant. We found that gut-processed fragments of OVA circulate in the serum $60 \mathrm{~min}$ after feeding of OVA to adult mice, and that these can induce tolerance for CMI in adult recipients of such serum (25). But it has also been shown that in vitro digestion of bovine serum albumin leads to generation of both tolerogenic and immunogenic fragments (7), and so it is conceivable that alterations in in vivo digestion of OVA are the explanation for the unusual immune responses to ingested OVA in the newborn.

A working hypothesis to explain the findings of our series of experiments has to take into account digestive and immunologic functions, and the fact that differences in retolerisability for antibody and CMI responses have been demonstrated. We pos tulate that after a neonatal antigen feed, immunologic and digestive immaturity lead to a net gain in T help, which prevents the induction of tolerance due to $\mathrm{T}$ suppressor cells. The difference between antibody and CMI responses can be explained if memory cells for antibody responses have a shorter lifespan than $\mathrm{T}$ effector cells for DTH, or T memory cells for DTH. Although transferability of DTH has usually been found to be limited to a short period after immunisation, it has also been shown that DTH effector cells may be long-lived (23). Much further work will be required to investigate the role of the gut as a regulator of immune responses to fed antigens and to examine the subse- 
Table 5. Effects of intra-amniotic ovalbumin (OVA) injections and an OVA refeed at $28 d$ on subsequent immune responses of $B D F_{1}$ mice*

\begin{tabular}{|c|c|c|c|c|c|}
\hline Group & $\begin{array}{l}\text { Intra-amniotic } \\
\text { injection at } \\
\text { age } 1 \mathrm{~d}\end{array}$ & $\begin{array}{c}\text { Feed at } \\
\text { age } 28 \mathrm{~d}\end{array}$ & $\begin{array}{c}\text { Specific } 24 \mathrm{~h} \\
\text { footpad increment } \\
(\text { mean } \pm 1 \mathrm{SD})\end{array}$ & $\begin{array}{l}\log _{10} \text { antibody } \\
\text { titres } 3 \text { wk after } \\
\text { immunisation } \\
(\text { mean } \pm 1 \mathrm{SD})\end{array}$ & $\begin{array}{l}\text { Animals } \\
\text { per group }\end{array}$ \\
\hline A & SAL & SAL & $0.17 \pm 0.03 \dagger$ & $3.29 \pm 0.22$ & 5 \\
\hline B & SAL & OVA & $0.03 \pm 0.01$ & $2.60 \pm 0.20 \S$ & 5 \\
\hline $\mathrm{C}$ & OVA & OVA & $0.14 \pm 0.03 \ddagger$ & $2.59 \pm 0.19 \S$ & 5 \\
\hline
\end{tabular}

* All animals were immunised $7 \mathrm{~d}$ after feeding.

$\dagger P<0.001$ compared with Group B.

$\ddagger P<0.005$ compared with Group B.

$\S P<0.01$ compared with Group A.

Effects of an OVA feed on day 1 and an OVA refeed on subsequent immune responses compared to tolerant controls

$\left(B D F_{1}\right)$

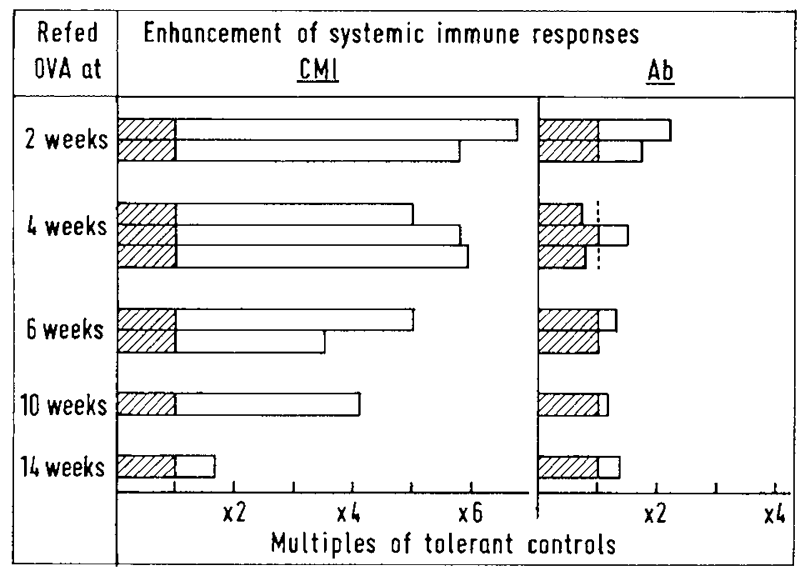

D+7 OVA / CFA

Fig. 3. Effects of an ovalbumin (OVA) feed on the first day of life and on OVA refeed on subsequent immune responses compared with tolerant controls $\left(\mathrm{BDF}_{1}\right)$. Broken line indicates mean of tolerant controls.

quent systemic immune responses at the cellular level (24). This should be directed towards the documentation of development of the mucosal immune system, both with respect to immunoregulatory and effector functions. It will always also be essential to examine the immunochemical properties of immunogenic materials which are found in blood after enteral administration. Our experiments have addressed only those antibody responses detected by passive haemagglutination and ELISA techniques, as well as CMI. Subsequent work should also concern the effects of neonatal antigen exposure on IgE antibodies. Nevertheless, the work described above should provide a structured basis for investigation of an important clinical problem: that feeding protein antigens to human neonates at a time when both digestive and immune systems are immature sometimes sensitises the infant for potentially harmful immune responses to foods, and thereby food allergic diseases.

\section{REFERENCES AND NOTES}

1. André, C., Heremans, J. F., Vaerman, J. P., and Cambiaso, C. L.: A mechanism for the induction of immunological tolerance by antigen feeding: antigenantibody complexes. J. Exp. Med. 142: 1509 (1975)

2. Billingham, R., and Brent, L.: Acquired tolerance of foreign cells in newborn animals. Proc. R. Soc. London (Ser B), 146: 78 (1956).

3. Brambell, F. W. R.: The transmission of immunity from mother to young and the catabolism of immunoglobulins. Lancet, 2: 1087 (1966).

4. Clark, S.: The ingestion of proteins and colloidal materials by columnar absorptive cells of the small intestine in suckling rats and mice. J. Biophys. Biochem. Cytol., 5: 41 (1959).

5. Chiller, J., and Weigle, W. O.: Cellular events during induction of immunologic unresponsiveness in adult mice. J. Exp. Med., 106: 1647 (1971).
6. Dixon, F. J., and Weigle, W. O.: The nature of immunological inadequacy of neonatal rabbits. II antibody formation by neonatal spleen cells transferred to adult receipients. J. Exp. Med., 110: 139 (1959).

7. Dosa, S., Pesce, A. J., Ford, D. J., Muckerheide, A., and Michael, J. G.: Immunological properties of peptic fragments of bovine serum albumin Immunology, 38: 509 (1979).

8. Eastham, E. J., Lichauco, T., Grady, M. I., and Walker, W. A.: Antigenicity of infant formulas: role of immature intestine in protein permeability. $\mathbf{J}$. Paediatr., 93: 561 (1978)

9. Etlinger, $H$. and Chiller, J.: Maturation of the lymphoid system I. Induction of tolerance in neonates with a $T$ dependent antigen that is an obligate immunogen in adults. J. Immunol., 122: 2558 (1979).

10. Ferguson, A., Parrott, D. M. V.: The effect of antigen deprivation on thymus dependent and thymus independent lymphocytes in the small intestine of the mouse. Clin. Exp. Immunol., 12: 477 (1972).

11. Ferguson, A., Gerskovitch, V. P., and Russell, R. I.: Pre and postweaning disaccharidase patterns in isografts of fetal mouse intestine. Gastroenterology, 64: 292 (1973)

12. Hanson, D., Vaz, N., Maia, L., Hornbrook, M., Lynch, J., and Ray, L.: Inhibition of specific immune responses by feeding protein antigens. Int. Arch. Allergy Appl. Immunol., 55: 526 (1977).

13. Hanson, D.: Ontogeny of orally induced tolerance to soluble proteins in mice. I Priming and tolerance in newborns. J. Immunol., 127: 1518 (1981).

14. Joel, D. D., Hess, M. W., and Cottier, H.: Thymic origin of lymphocytes in developing Peyer's patches of newborn mice. Nature New Biol., 231: 24 (1971).

15. Joel, D. D., Hess, M. W., and Cottier, H.: Magnitude and pattern of thymic lymphocyte migration in neonatal mice. J. Exp. Med., 135: 907 (1972).

16. Kagnoff, M. F.: Effects of antigen feeding on intestinal and systemic immune responses IV Similarity between the suppressor factor in mice after erythrocyte-lysate injection and erythrocyte feeding. Gastroenterology, 79: 54 (1980).

17. Morris, I.G.: Gamma globulin absorption in the newborn. In: Code, C. F. and Heidel, W.: Handbook of Physiology. Alimentary Canal, Vol. 2, p. 1491 (Williams and Wilkins Baltimore, 1968)

18. Mowat, A. Mcl., and Ferguson, A.: Hypersensitivity reactions in the small intestine. 5 Induction of cell mediated immunity to a dietary antigen. Clin. Exp. Immunol., 43: 574 (1981).

19. Mowat, A. McI., Strobel, S., Drummond, H. E., and Ferguson, A.: Immunological responses to fed protein antigens in mice 1. Reversal of oral tolerance to ovalbumin by cyclophosphamide. Immunology, 45: 105 (1982).

20. Murgita, A. and Wigzell, H.: Regulation of immune functions in the fetus and newborn. Progr. Allergy, 29: 54 (1981).

21. Ngan, J. and Kind, L.: Suppressor $T$ cells for $\operatorname{lgE}$ and $\operatorname{IgG}$ in Peyer's patches of mice made tolerant by the oral administration of ovalbumin. J. Immunol., 120: 861 (1976).

22. Ptak, W. and Skowron-Cendrzak, A.: Fetal suppressor cells. Their influence on the cell mediated immune responses. Transplantation, 24:45 (1977).

23. Shiho, O., Takaoki, M., Nakagawa, Y., Arakawa, M., and Takeuchi, M. Carrier-induced $\mathrm{T}$ helper and $\mathrm{T}$ suppressor cells involved in the regulation of hapten-specific DTH responses. J. Immunol., 129: 966 (1982).

24. Strobel, S. and Ferguson, A.: Effects of neonatal antigen feeds on subsequent systemic and local CMI responses. Gut, 23: A895 (1982).

25. Strobel, S., Mowat, A. McI., Pickering, M. G., and Ferguson, A.: Immunological responses to fed proteins in mice. 2. Oral tolerance for CMI is due to activation of cyclophosphamide sensitive cells by gut processed antigen. Immunology, 49: 451 (1983).

26. Thomas, H. C. and Parrott, D. M. V.: The induction of tolerance to a soluble protein antigen by oral administration. Immunology, 27:63 (1974).

27. Tomasi, T. B.: Oral tolerance. Transplantation, 29: 353 (1980).

28. Vaz, N., Maia, L., Hanson, D., and Lynch, J.: Inhibition of homocytotropic antibody responses in adult inbred mice by previous feeding of the specific antigen. J. Allergy Clin. Immunol., 60: 110 (1977).

29. Walker, W. A. and Isselbacher, K. J.: Uptake and transport of macromolecules by the intestine: possible role in clinical disorders. Gastroenterology, 67: 531 (1974). 
30. Wells, H. G., Osborne, T. B. The biological reactions to vegetable proteins. I. Anaphylaxis. J. Infec. Dis., 8: 66 (1911).

31. We wish to thank the staff of the Animal Unit of the Western General Hospital Dr. Donald Hanson, for many stimulating discussions, Margarct Gordon for expert technical assistance, and Doreen Orr and Hilary Burns for excellent secretarial help in the preparation of this manuscript. This work was supported by a grant from the Deutsche Forschungsgemeinschaft (DFG Str 210 1 and 210/2-3) and the Medical Rescarch Council.
32. Requests for reprints should be addressed to: Dr. Stephan Strobel, GastroIntestinal Unit Western General Hospital. Crewe Road. Edinburgh EH4 $2 \mathrm{XU}$, United Kingdom

33. This research was supported by grants from the Medical Research Council and the Deutsche Forschungsgemeinschaft

34. Received for publication March 14, 1983

35. Accepted for publication August 12.1983.

\title{
Calcium Metabolism and Cystic Fibrosis: Mitochondrial Abnormalities Suggest a Modification of the Mitochondrial Membrane
}

\author{
AXEL A. VON RUECKER, ROSEMARIE BERTELE, AND H. KARSTEN HARMS
}

Universitaets Kinderklinik, Munich, Federal Republic of Germany

\section{Summary}

A disorder of calcium $\left(\mathrm{Ca}^{2+}\right)$ metabolism may be central to the pathogenesis of cystic fibrosis (CF). Average cellular $\mathrm{Ca}^{2+}$ levels in fibroblasts derived from patients with CF (ages, 14-25 yr; $n$ $=25$ ) were $36-77 \%$ higher than in matched controls depending on age of cell culture $(9.0-10.6$ versus $5.1-7.8 \mathrm{nmol} / \mathrm{mg}$ cellular protein). Cellular $\mathrm{Ca}^{2+}$ was significantly elevated in $\mathrm{CF}$, but was not a reliable criterion for identifying $\mathrm{CF}$ cells because of the high variability of results. Studies of $\mathrm{Ca}^{2+}$ fluxes in cell organelles showed that mitochondria isolated from $\mathrm{CF}$ fibroblasts accumulate 2-3 times more $\mathrm{Ca}^{2+}$ than controls $179.5 \pm 8.2$ versus 33.7 $\pm 4.7 \mathrm{nmols} \cdot \mathrm{mg}$ mitochondrial protein $\left.{ }^{-1} \cdot 10 \mathrm{~min}^{-1}( \pm \mathrm{SD})\right] \cdot \mathrm{Ca}^{2+}$ accumulation in mitochondria reliably distinguished between $\mathrm{CF}$ and control or heterozygote cells $(P<0.0005, n=11)$.

In vitro experiments showed that $\mathrm{Ca}^{2+}$ influx and efflux are increased in isolated $\mathrm{CF}$ mitochondria, resulting in net $\mathrm{Ca}^{2+}$ accumulation. $\mathrm{Ca}^{2+}$ uptake in mitochondria is energy-dependent; some inhibitors of mitochondrial energy metabolism (atractyloside, oligomycin) influenced $\mathrm{Ca}^{2+}$ uptake significantly more in $\mathrm{CF}$ than in control mitochondria. Furthermore, the average activities of NADH oxidase, NADH- and succinate-cytochrome c reductase were 77,58 , and $48 \%$ higher in CF mitochondria, respectively. This indicates that many functions associated with energy metabolism and the mitochondrial membrane (electron transport, ATP transport, and ATP hydrolysis) are not operating properly in $\mathrm{CF}$, thus possibly causing the derangement of $\mathrm{Ca}^{2+}$ metabolism found in CF mitochondria and cells.

\section{Abbreviation}

\section{$\mathrm{CF}$, cystic fibrosis}

An interesting feature of $\mathrm{CF}$ research is the multiformity of results reported in the literature $(8,33,34)$. Only recently, studies of the Vatican records on dispensations for cousin-cousin marriages have confirmed that $\mathrm{CF}$ is a monogenic autosomal recessive disease with an incidence of up to 1 in 1600 in some Caucasian populations (i.e., northern Europe) (9). Because only a single gene must account for all the phenomenons of $\mathrm{CF}$, it seems reasonable to conceive a working model which would explain this heterogenous exocrinopathy that still is the most common lethal genetic disease in Europe and the United States (8. 35).

CF must surely involve some basic event of cellular function or the diversity of reported results is hardly comprehensible. The emphasis of our studies was put on $\mathrm{Ca}^{2+}$ metabolism which has been suggested to be central in the pathogenesis of CF by various authors $(2,3,16,18,28) \mathrm{Ca}^{2+}$, an intracellular messenger, is linked to many cellular functions $(e . g .$, secretion, protein phosphorylation and activation, and protein synthesis: for a recent review see ref. 7). A derangement, therefore, of cellular $\mathrm{Ca}^{2+}$ can cause a variety of different phenomenons, making it a possible candidate for explaining the manifold features reported in CF.

Our study's first aim was to quantify elevated intracellular $\mathrm{Ca}^{2+}$ in $\mathrm{CF}$ and see if it is possible to establish a simple and reliable test to discriminate between $C F$ and control cells on this basis. Second, $\mathrm{Ca}^{2+}$ metabolism was studied in cell organelles (mitochondria. endoplasmic reticulum) that account for 95-98\% of intracellular $\mathrm{Ca}^{2+}$ and presumably must be affected if intracellular $\mathrm{Ca}^{2+}$ is significantly altered. Our investigations centered on the energy-dependent $\mathrm{Ca}^{2+}$ uptake and $\mathrm{Ca}^{2+}$ efflux in mitochondria which showed to be definitely altered in CF cells. By employing different inhibitors of mitochondrial $\mathrm{Ca}^{2+}$ uptake ATP transport, ATP hydrolysis and electron transfer, and by measuring clectron transfer activities directly, changes in mitochondrial $\mathrm{Ca}^{2+}$ and energy metabolism could be detected in $\mathrm{CF}$. The suggestion of a mitochondrial focus in CF, first made by Feigal and Shapiro, was confirmed $(11,28)$.

\section{MATERIALS AND METHODS}

Cell cultures. Fibroblast cultures were obtained from biopsy specimens of the forearm, after informed consent had been obtained. Thirty-two patients with CF (14-25 yr; mean, $17.3 \mathrm{yr})$ were studied. Their clinical status varied from good to severe with Shwachmann scores (31) varying between 34 and 92. Furthermore, 28 obligate $C F$ heterozygotes $(21-33 \mathrm{yr}$; mean, 29.1 $\mathrm{yr}$ ) and 51 controls (14-30 yr; mean, $18.4 \mathrm{yr}$ ) with no signs of pulmonary disease and in good clinical condition were studied. 